\title{
Development of and production update for the Grasberg Block Cave mine - PT Freeport Indonesia
}

\author{
C Brannon Freeport-McMoRan Inc., United States \\ D Beard Freeport-McMoRan Inc., United States \\ N Pascoe PT Freeport Indonesia, Indonesia
}

A Priatna PT Freeport Indonesia, Indonesia

\begin{abstract}
This paper provides an update of the mine design, construction, caving progress and operations status of the Grasberg Block Cave (GBC) mine. Undercutting was initiated in September 2018 and drawbelling in December 2018. Undercutting is currently proceeding in three production blocks. Full production is expected in 2025, a 21-year time period between initial access development in 2004 to full production. Diluted ore reserves are about 959 million tonnes at a grade of $0.97 \% \mathrm{Cu}$ and $0.73 \mathrm{~g} / \mathrm{t} \mathrm{Au}$. The mine plan utilizes an El Teniente-style drawpoint layout on a $20 \mathrm{~m} \times 30 \mathrm{~m}$ drawbell spacing, comprising some 2,400 drawpoints in a 720,000 $\mathrm{m}^{2}$ footprint. The drawpoint opening sequence comprises eight production blocks. Ore is transported via diesel-powered LHDs to a series of ore passes, then via loading chutes to a rail haulage system, which delivers the ore to a three-gyratory crusher complex. Crushed ore is transported to the mill stockpiles via dual inclined conveyors. Development and construction of the initial fixed facilities was completed in late 2018 and expansion of those facilities is ongoing to support production ramp up. Primary access for workers and materials is via the $6-\mathrm{km}$ long $A B$ adits. The service shaft for hoisting workers and materials from the $A B$ adits' level to the various operating levels was commissioned in 2016. The rail haulage central control system and initial haulage operating areas were commissioned in 2018. The first phase of the crusher/conveyor system was commissioned in mid-2018. Ventilation is provided through a series of large intake and exhaust drifts; four 5,000 kW main fans are operational, and a fifth fan will be commissioned in 2021. A 1,600 l/s pumping system will manage drainage from the mine. The initial stage of the pumping system is under construction and will be commissioned in 2020.
\end{abstract}

\section{Introduction}

PT Freeport Indonesia (PTFI) began the development of the Grasberg Block Cave Mine (GBC) with initial access drifting in 2004, 14 years before the initiation of caving in late 2018 and about 21 years before achieving full production rates of 130,000 to 160,000 t/d of ore by 2025 .

The four currently active underground mining operations in the Grasberg Mining District are the GBC (target 130-160 kt/d ore), the Deep Ore Zone (DOZ) block cave mine (25 kt/d), the Deep Mill Level Zone (DMLZ) block cave mine (target $80 \mathrm{kt} / \mathrm{d}$ ), and the Big Gossan open stoping operation $(7 \mathrm{kt} / \mathrm{d}$ ). The Kucing Liar orebody is another large caving operation that will begin development in 2021 and begin production in 2027. The Grasberg Open Pit has been in production since 1990 with active pit production essentially ending in late 2019. Figure 1 is a schematic view of the Grasberg District orebodies. The concentrating plant has a peak capacity of about $240 \mathrm{kt} / \mathrm{d}$. When open pit mining concludes, peak production targets from the district will remain at $240 \mathrm{kt} / \mathrm{d}$ and will be entirely from underground. The $\mathrm{GBC}$ will be the primary source of mill feed (target $130-160 \mathrm{kt} / \mathrm{d}$ ). 


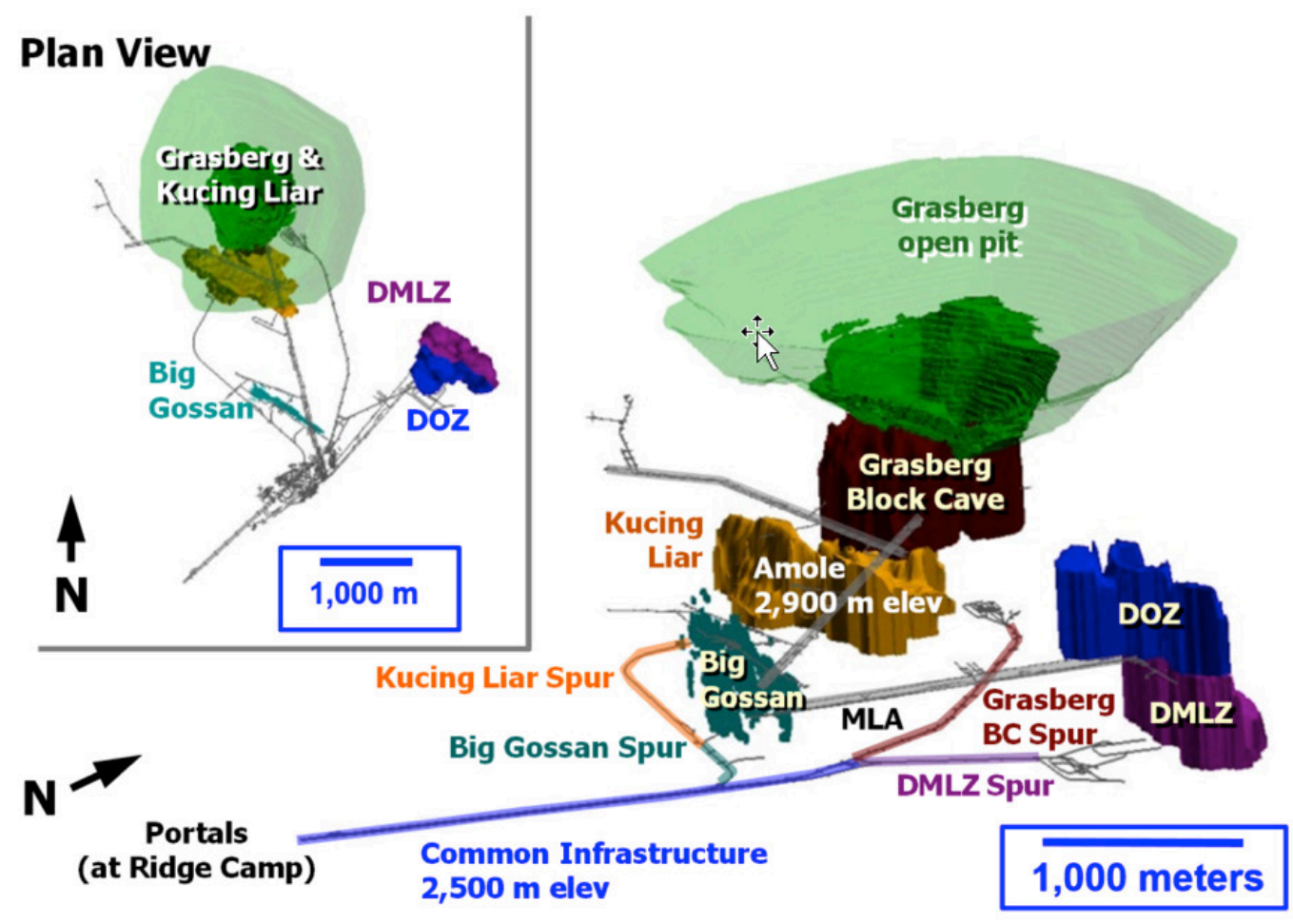

Figure 1 Perspective view of the Grasberg District orebodies and major accesses

This paper provides an update to the progress of the development, construction and production of the GBC mine. A paper presented at MassMin 2016 (Brannon et al. 2016) summarized the key design parameters of the $\mathrm{GBC}$ at that time. A related paper discussing the GBC caving sequence and undercut planning was presented at the Caving 2018 conference in Vancouver (Beard \& Brannon 2018).

\section{Geology, ore reserves and caving plan}

\subsection{Geology and ore reserves}

GBC estimated diluted ore reserves (at the end of 2019) are 959 million tonnes at a grade of $0.97 \%$ copper and $0.73 \mathrm{~g} / \mathrm{t}$ gold, representing payable metal of 17 billion pounds copper and 14 million ounces gold. Annual average metal production (at full production rates) is approximately 850 million pounds copper and about 700,000 ounces of gold.

The Grasberg deposit is a porphyry copper-gold deposit comprising a multi-stage dioritic intrusion emplaced into the center of a volcanic breccia complex. Mineralization extends more than 1,600 $\mathrm{m}$ vertically, from the 4,300 m elevation at the original surface to at least a depth of 2,600 $\mathrm{m}$. The width of the mineralization ranges from about $200 \mathrm{~m}$ to over one kilometer. The central Kali diorite late intrusive phase forms about a 100-m wide septum of barren and weakly altered rock that cuts through the otherwise roughly cylindrical, mineralized intrusive complex. This results in a horseshoe-shaped ore footprint in the plan view (Figure 2). The highest grades of the deposit are centrally located within the intrusive complex around the central Kali barren zone.

Note that the mineralized zone actually extends across and between production blocks PB1N and PB2N. However that section contains the required permanent access across the mine footprint and so has been removed from the caving plan. 


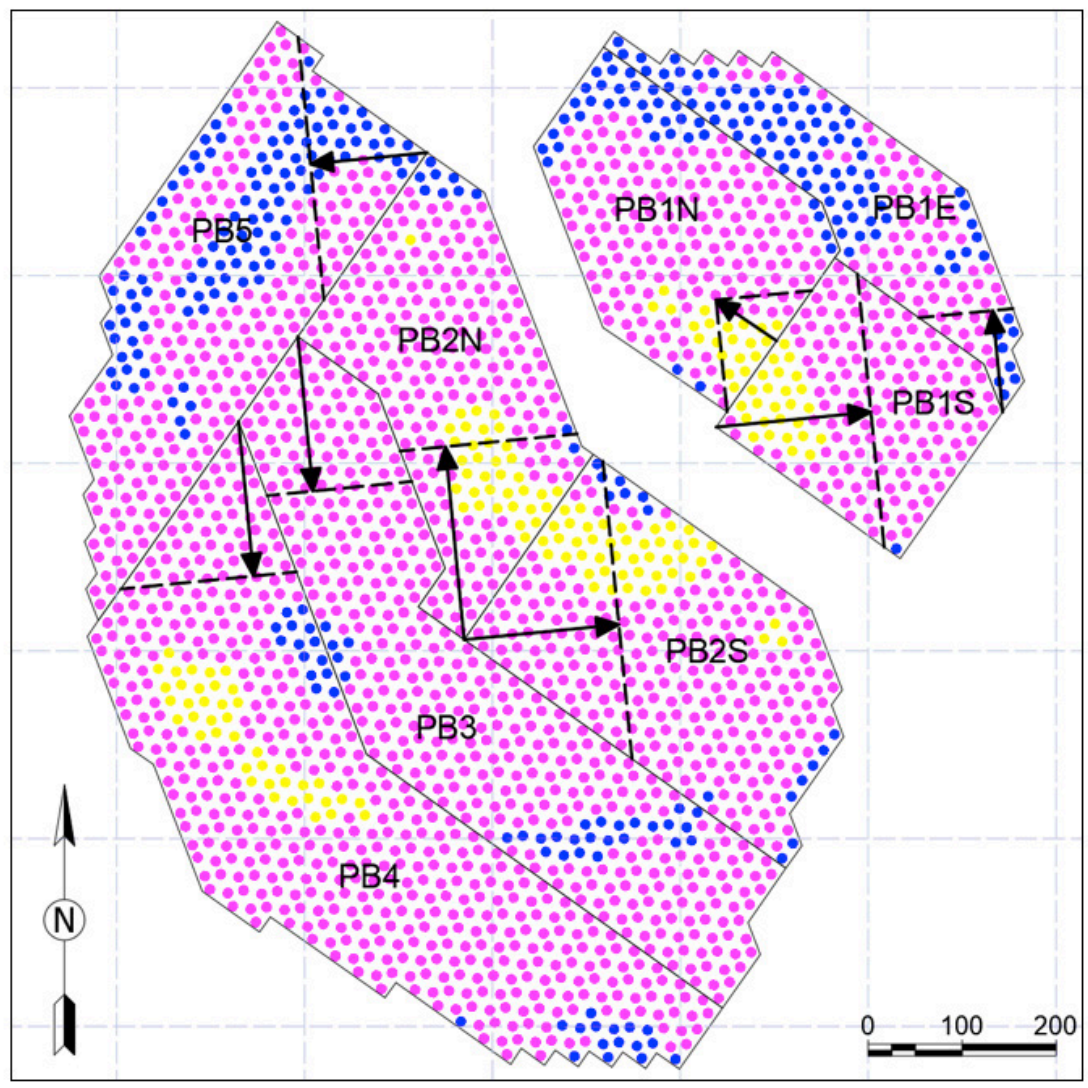

Figure 2 GBC footprint showing grade distribution (yellow - lighter = higher grade, blue - darker = lower grade), production block caving directions and naming conventions

The Kali diorite is a unit of generally very good ground that provides a location for a permanent central access across the orebody. The Kali diorite also extends to the southeast, beyond the boundaries of the Grasberg Intrusive Complex (GIC) and provides a location for the fixed facilities of the mine. The layouts for those fixed facilities were adjusted to the extent possible to stay within the better ground conditions provided by the Kali diorite.

The GBC is located below the two-kilometer diameter Grasberg open pit, which is in the final months of production after being in production for more than 20 years. The final pit bottom is just under 200 $\mathrm{m}$ above the Extraction Level (2,830 $\mathrm{m}$ elevation). The cave reserve has average column heights of about $500 \mathrm{~m}$. Pit slope stability, extensively modeled during the mine design process, predicts slope failures shortly after caving commences. The projected failure geometries, grades and material types in those failure areas are incorporated into the dilution modeling for the GBC mine reserve. Projected dilution volumes comprise about $20 \%$ of the GBC reserves.

\subsection{Caving and production plan}

\subsubsection{Caving plan}

The GBC orebody has a large footprint of $700,000 \mathrm{~m}^{2}$ with a diameter of about one kilometer. The Extraction Level (2,830 m elevation) is an El Teniente-style layout with production panel drifts spaced at $30 \mathrm{~m}$ and drawpoints spaced at $20 \mathrm{~m}$. The Extraction Level contains about 2,400 drawpoints. The Undercut Level is $20 \mathrm{~m}$ above the Extraction Level. The overall footprint is divided into eight production blocks. The mining sequence prioritizes the blocks with the highest grades in the early years. Production has been initiated in Production Blocks 1, 2S and 2N (Figure 2) simultaneously in order to accelerate the ramp-up period.

The mine is a panel caving operation with planned peak production of 130,000 to $160,000 \mathrm{t} / \mathrm{d}$. Peak production is planned in 2025, and the mine closure in 2041. To meet its production target, a number of production blocks will be operating at the same time. At full production, four to five separate production 
blocks will be operating. Because the highest value of the mine is concentrated into the central core of the deposit, the initial production blocks will start caving simultaneously on either side of the barren central Kali diorite and move progressively away from that central zone.

The currently active production blocks are undercut using a "crinkle-cut" drill ring design and blasting pattern similar to that successfully employed in the currently active DOZ and DMLZ block cave mines. The mine uses an advance undercut mining sequence, with the leading edge of the undercut a minimum of $20 \mathrm{~m}$ ahead of drawbelling on the Extraction Level.

The first two production blocks (PB1S \& PB2S) were completely excavated and drawpoints constructed ahead of the undercut advance, with the exception of the pillar within the drawbell. That pillar is then blasted and the drawbell taken once the undercut has passed over. Subsequent production blocks (including PB2N) have a revised mining sequence in which only the panel drives are excavated prior to the undercut advance. Then in the shadow of the cave front, the drawpoint drives are excavated and drawpoints constructed. The intent is to reduce the volume of excavated ground to help limit the damage to the production areas prior to caving and production.

A maximum undercutting rate of about $8,000 \mathrm{~m}^{2}$ per month is forecast during the initial ramp-up period years. This undercutting rate is the total of all active production blocks. There is a planned maximum undercutting rate of $4,000 \mathrm{~m}^{2}$ per month per production block. Once the initial ramp-up is achieved the total undercutting rates average about 3,000 to 4,000 $\mathrm{m}^{2}$ per month during steady state full production. The typical undercutting rate per production block is about $2,500 \mathrm{~m}^{2}$ per month when three to four production blocks are active. Lead-lag target is $13 \mathrm{~m}$ with a minimum and maximum criteria set at 7 and $20 \mathrm{~m}$, respectively. Ring blasts are on a $2.2 \mathrm{~m}$ spacing and $2.2 \mathrm{~m}$ burden. The minimum and maximum undercut advance rates are currently set at two rings per month $(5 \mathrm{~m})$ and eight rings per month (18 $\mathrm{m})$.

Maximum undercut front length is about $250 \mathrm{~m}$ (measured at right angles to the drill drives). Maximum undercut front length measured along the cave front is $350 \mathrm{~m}$. The production forecast assumes a maximum drawbell opening rate of five drawbells per month per production block and about 12 drawbells per month across all active production blocks.

A particular challenge on the Extraction Level will be the transition from an active production block to the new, adjacent production block, as caving will be propagating in the active block as the adjacent block is being initiated. Abutment stresses and early dilution are well-known risks when starting a new block against an active block. The current plan is to fully develop the production panels and drawpoints along the block boundaries and allow caving to propagate into the new block. The risks that the drawpoints at the block boundaries may become "sacrificial" are understood. Boundary drawpoints will probably be drawn at a lower rate or not drawn from at all in order to provide a dilution boundary between the two adjacent active blocks. There is the potential for significant damage to these boundary drawpoints due to abutment loading from the adjacent cave. Studies are ongoing to optimize the caving plan in terms of production and mitigation of geotechnical risk.

A major challenge will be managing the interaction of the Grasberg Block Cave with the Grasberg Open Pit. Developing one of the largest block caves in the world, below one of the largest open pits, in an area that receives greater than $5 \mathrm{~m}$ of rain a year will be extremely challenging. The connection of the block cave to the open pit will allow water and, potentially, dilution into the draw columns resulting in an increased risk of wet muck rushes. As of June 2020, the seismic activity from the cave back for PB2SPB2N was approaching the pit wall and some indications of imminent breakthrough were taking place.

\subsubsection{Caving sequence}

Various mining sequences have been assessed using numerical simulations by Beck Engineering (Campbell et al. 2016; Campbell et al. 2020). These simulations have provided valuable information about the anticipated stresses and deformation that may be encountered during the development and subsequent production of the Grasberg Block Cave. 
The current planned caving sequence is shown on Figure 3. Production has been initiated in blocks PB2S and PB1S. Initial caving in in PB2N lagged somewhat behind the adjacent PB2S block, but that cave front has essentially now caught up to the cave front in PB2S.

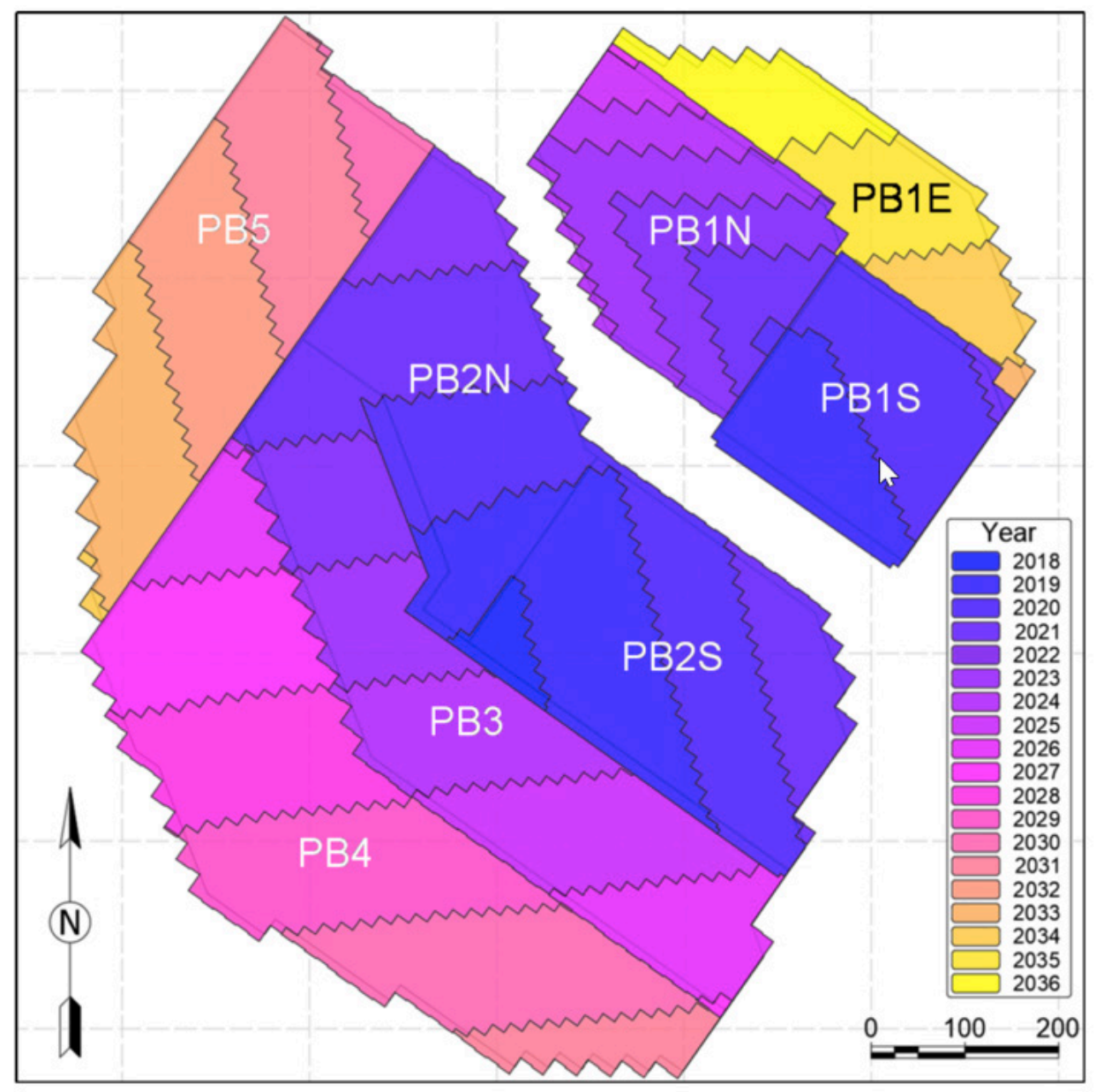

Figure 3 Current overall GBC undercutting sequence - Ring blasting by year

\subsubsection{Current production status (June 2019)}

Undercutting was initiated in late 2018 and the initial drawbelling commenced in January 2019. As of June 2020, total area undercut comprises about 129,000 $\mathrm{m}^{2}$ from three production blocks. About 147 drawbells have been blasted (294 drawpoints). Current daily production is about 35,000 t/d.

The PB2S-PB2N production blocks reached critical hydraulic radius of about $>35$ in August 2019, and is fully propagating (Figure 4). The PB1S production block reached critical hydraulic radius of about 35 in March 2020. The status of undercutting and drawbelling through June 2020 is shown on Figure 5. At the time of this writing the cave-open pit interaction was accelerating and the breakthrough of the cave appeared imminent.

Additional details on the caving parameters and current status of the cave can be found in another MassMin 2020 paper (Campbell et al. 2020). 


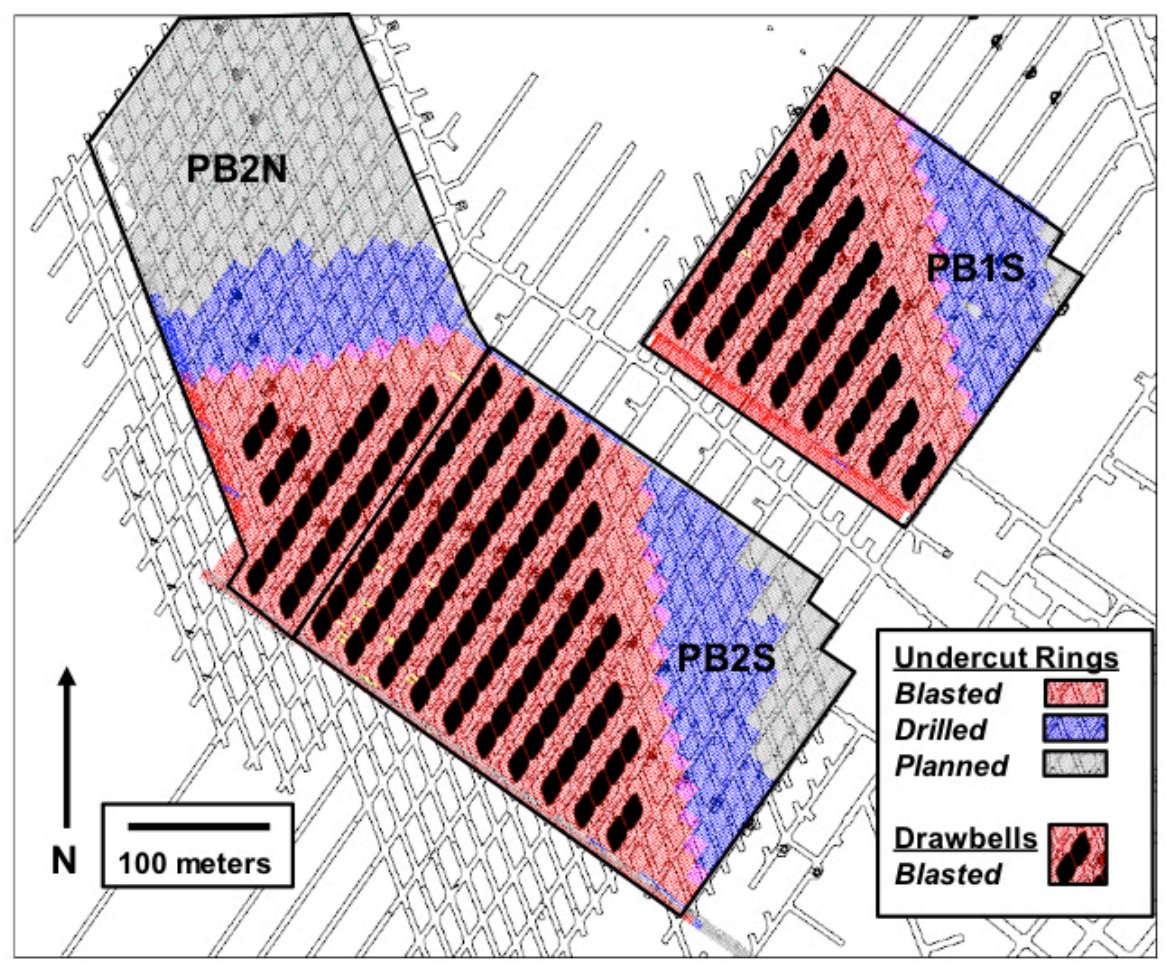

Figure 4 Undercutting and drawbelling in production blocks PB1S, PB2S and PB2N
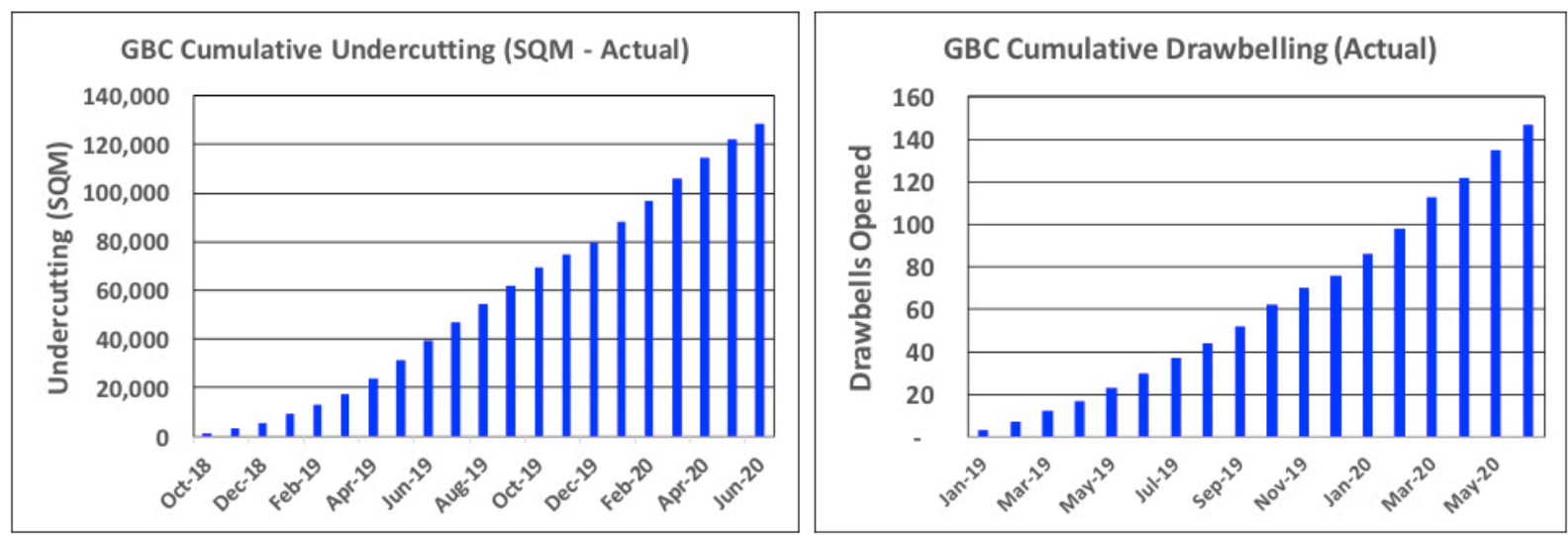

Figure 5 Undercutting and drawbelling progress to date

\section{$3 \quad$ Mine design and construction status}

\section{$3.1 \quad$ Overview}

Figure 6 shows a schematic section of the GBC mine design and locations of some of the major facilities in the mine relative to the orebody.

The total linear meters of development at the time of start of caving was about 250,000 m, including accesses, ventilation drifts, ore flow systems, fixed facilities, and production areas. An additional $100,000 \mathrm{~m}$ will be developed through the ramp-up period to full production. Monthly development drifting currently averages about 2,000 linear meters per month. Delineation drilling, dewatering and geotechnical monitoring will be ongoing as sites become available within the orebody. Construction of the fixed facilities began in mid-2015. Those facilities continue to be expanded to accommodate the needs for full production, but are now operational on all production levels. 


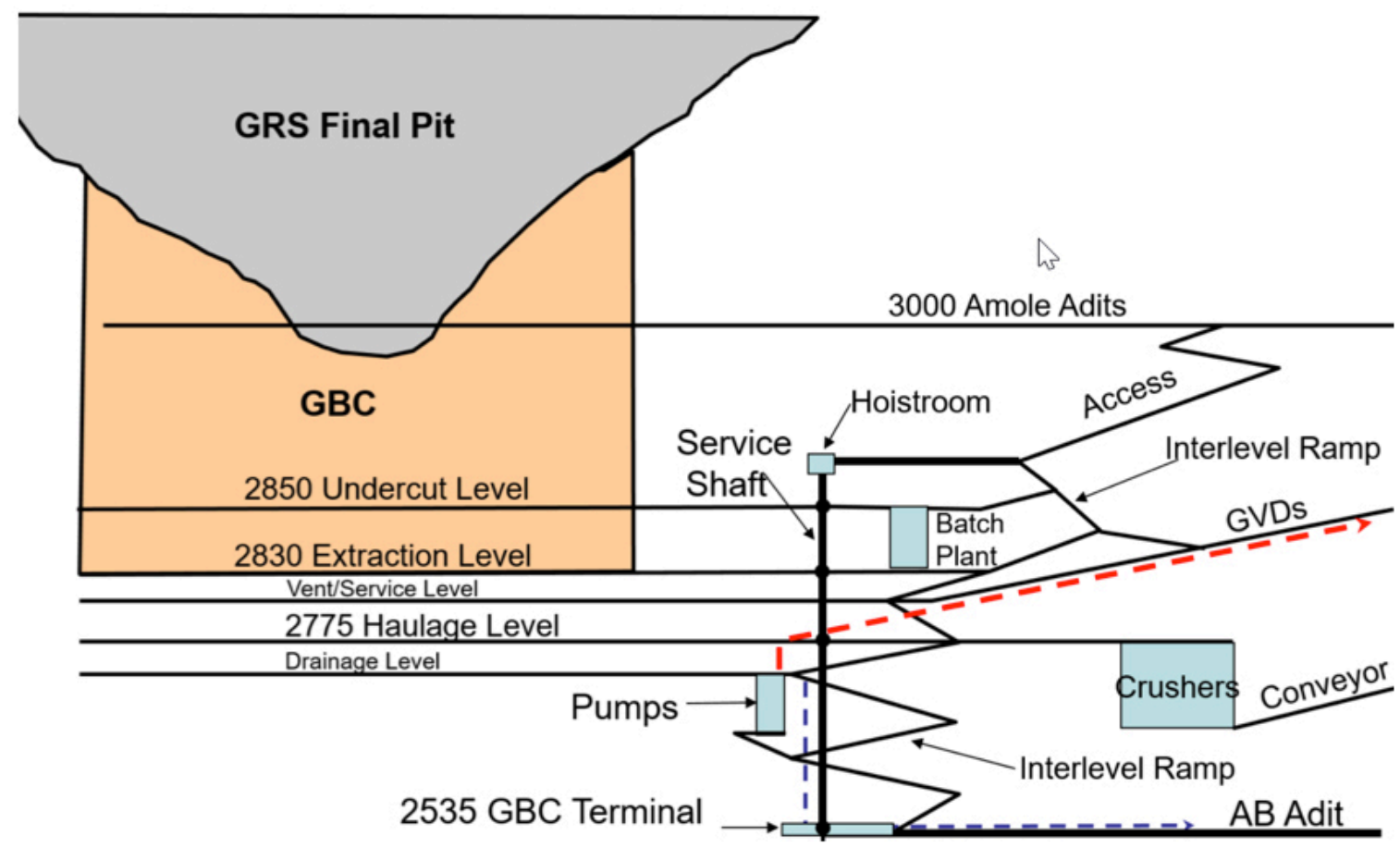

Figure 6 Schematic section of the GBC mine and major facilities

The primary access to the mine is through the 6-kilometer long $A B$ adits developed from surface at the 2,500 m level (CIP - "Common Infrastructure" area). The surface CIP yard has major facilities for the mines including bus terminal, maintenance, warehousing, materials handling, batch plants, and aggregate plants. The main office complex for the underground mines is at the surface CIP facility. Control rooms in that office remotely operate production loaders, loading chutes, the ore haulage rail system, the ore haulage unloading station, and rock breakers at the production panels.

Rubber tire equipment uses the $A B$ adits to deliver manpower and materials to the mine and to haul development muck out of the mine. The $A B$ tunnel system has been completed for the GBC and DMLZ mines and will ultimately comprise about $18 \mathrm{~km}$ of roadways servicing all of the underground mines. A traffic control system is installed to control the movements of all vehicles to and from the mine; that control system is operated remotely from the surface main office complex. The AB tunnels also provides a route for gravity drainage of water from all of the underground mines.

\subsection{Facilities description}

\subsubsection{Service shaft}

The GBC Service Shaft from the AB Terminal level up to the operating levels is the primary mode of transportation for workers and materials. The shaft was commissioned in the fourth quarter of 2016 and final permits for operations received in the second quarter of 2017.

The internal shaft is a $353 \mathrm{~m}$ long, 8.5m- diameter, concrete-lined, vertical shaft, fitted with a large double-deck service cage running on tubular steel guides. The hoisting system employs a modified Blair Hoist arrangement, using only one compensating sheave arrangement for the two cage ropes while using only a single rope for the cage counterweight. The double-deck cage can accommodate a 38-tonne total payload and can accommodate up to 300 miners per trip. The cage is sized to handle full 20-foot containers of materials as well as the rail rolling stock including production locomotives. 
The operation currently moves about 700 men per day to and from the $A B$ terminal and the operating levels. The operation currently moves about 28 material containers per day from the $A B$ terminal to the operating level. Eighty percent of the materials are sand, gravel and cement for the large underground batch plant adjacent to the other fixed facilities on the Extraction Level. Materials are trucked in via the $A B$ tunnels, loaded by overhead cranes onto rail-mounted dolly cars and then shunted onto the cage. Each of the main operating levels use rail systems and shunting locomotives to deliver loaded containers to the warehouses, maintenance facilities, powder magazine and the batch plant loading bins.

\subsubsection{Batch plant}

The underground batch plant has played a key role in the construction of the mine. The batch plant is located adjacent to the Extraction Level fixed facilities to supply the required concrete and shotcrete. The plant has two completely redundant batching streams, each able to meet an average production of 250 $\mathrm{m}^{3} / \mathrm{d}$ shotcrete and concrete. There are two cement silos with total capacity for a two-day supply and an adjacent rail spur so that cement can be discharged directly from isotainers onto the rail-mounted dolly cars that are delivered from the shaft on the undercut level. At the Extraction Level, below the aggregate bins, loaders manually load directly from the bins to hoppers and into the cement mixers.

\subsubsection{Fixed facilities - AB terminal}

The facilities on this level are dedicated to the transfer of workers and materials from the $A B$ tunnels to the service shaft and out to the operating levels. The AB Terminal began operations in mid-2017 in parallel with the commissioning of the Service Shaft and has proven to be an efficient component of the operations and construction efforts. There are two 50-tonne overhead cranes that facilitate the loading and unloading of containers. Equipment and materials are transferred from rubber tire vehicles onto dolly cars to be placed on the service cage using shunting locomotives. Personnel travel via buses from the surface CIP yard to the $A B$ terminal where they load onto the cage for transport to the working levels.

\subsubsection{Fixed facilities - extraction level}

The majority of employees at the mine will work from the Extraction Level, and this level is the primary location for the GBC fixed facilities. Employees will access the level via the AB terminal and the service shaft. During peak periods, up to 900 people per shift will report to the level. In addition, the majority of the material loads, apart from batch plant consumables, are delivered to the Extraction Level.

The fixed facilities have been constructed in stages to support the construction effort and operations. The expansion of those facilities will continue through mid-2020 to completion.

The facilities on the Extraction Level comprise all aspects of the operation including shops, fuel and lube bays, warehousing, offices and control rooms, materials handling, and employee support facilities such as the potable water stations, sanitary facilities, mosque and chapel.

The main mess hall was converted to a 500-man permanent refuge chamber as part of the series of refuge chambers on the level to provide sanctuary for all workers if required (Figure 7). The mess facilities were reorganized to provide meals via a series of smaller satellite facilities that are located closer to the various parts of the operations. 


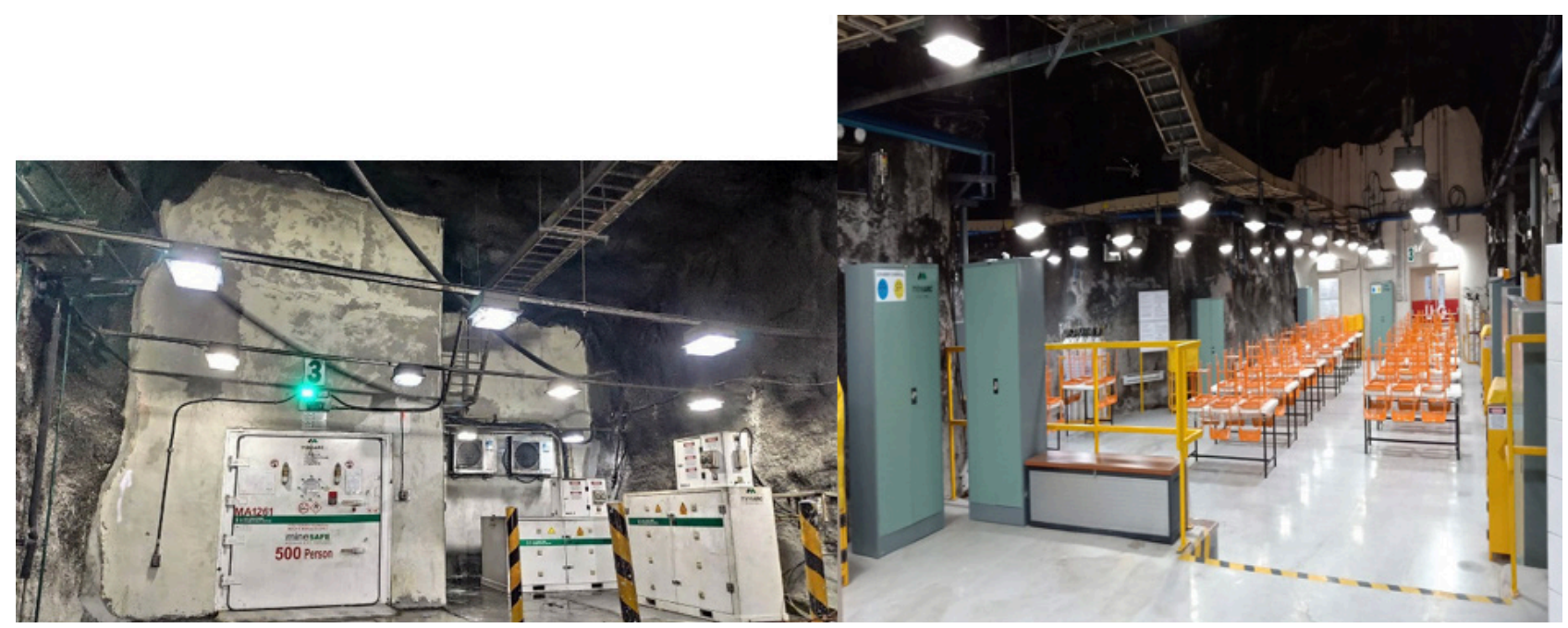

Figure 7 GBC 500-man permanent refuge chamber, showing one external entrance and one section of the interior of the chamber

\subsection{Backbone systems}

\subsubsection{Ventilation}

The ventilation system comprises of four 5,000 kW Howden Mixed Flow fans installed in a parallel exhausting configuration. Four main fans are in operation, and a fifth fan will be installed in 2021. Fresh air from the mill valley is downcast to the mine through four parallel primary intakes (GVD 1-4) mined at either $6.8 \mathrm{~mW} \times 9.0 \mathrm{mH}$ or $6.8 \mathrm{~mW} \times 12.0 \mathrm{mH}$ along a length of about $2.6 \mathrm{~km}$ from the portals to the service level. From the service level, air is distributed to the working areas of the mine using ventilation drifts and raises mined at various dimensions.

Exhaust air is upcast from the mine workings though four parallel primary exhaust drifts (GVD 5-8) mined at either $6.8 \mathrm{~mW} \times 9.0 \mathrm{mH}$ or $6.8 \mathrm{~mW} \times 12.0 \mathrm{mH}$ along a length of about $2.6 \mathrm{~km}$ from the service level to the portals. At the top of the exhaust, GVD's air passes through primary exhaust fans (located underground) before exhausting out four portals into the mill valley. Figure 8 displays the main components of the ventilation system. The current baseline estimate of the total airflow requirement for the GBC is $3073 \mathrm{~m}^{3} / \mathrm{s}$ occurring in 2023.

Although excavated at a large dimension, the length of the GVD intake and exhaust drifts imposes a practical limit on the total airflow capacity in the mine. The current estimated limit on total flow for the GBC mine is about 3,000-3,100 $\mathrm{m}^{3} / \mathrm{s}$ with four intakes and four exhaust GVDs at the original design dimensions of $6.8 \mathrm{~mW} \times 9.0 \mathrm{mH}$. Alternate configurations of the GVD drifts are currently being evaluated to address the difference between the total airflow requirement and the estimated capacity. It is anticipated that two to three of the GVD drifts on both exhaust and intake will need to be benched to a final height of $12 \mathrm{~m}$.

Using the baseline estimate the GBC mine utilizes $19.2 \mathrm{~m} / \mathrm{s} / \mathrm{kt} / \mathrm{d}$ (excluding the $285 \mathrm{~m}^{3} / \mathrm{s}$ used to ventilate the $A B$ Tunnels). Other block cave mines typically have ratios from 17 to $40 \mathrm{~m}^{3} / \mathrm{s} / \mathrm{kt} / \mathrm{d}$. The low ratio indicates that the GBC mine does not have excess air and that a significant ventilation management system will be required to maintain adequate airflows in all areas where personnel and equipment operate.

Approximately $50 \%$ of the airflow for the mine is used in extraction and development activities with the remainder used in fixed facilities, haulage, $A B$ Tunnel ventilation and crush/convey operations. Velocity requirements and diesel exhaust dilution requirements dictate $98 \%$ of the airflow primarily due to velocity requirements for dust control in the ore flow system and diesel dilution for development and production activities. 


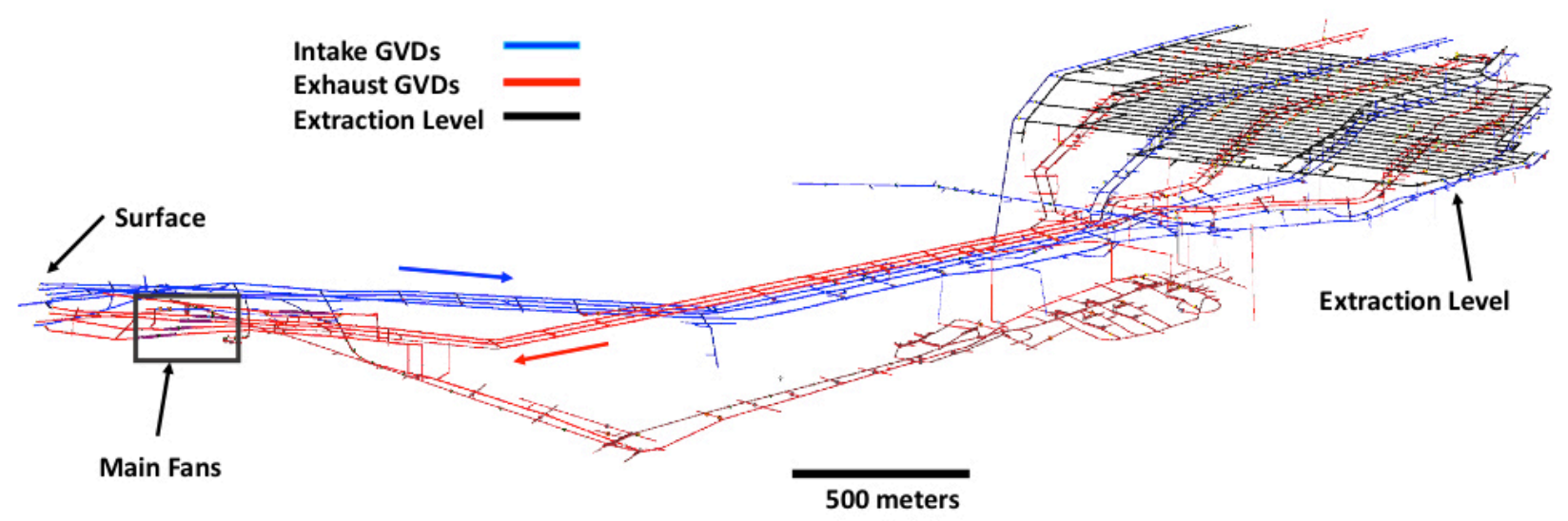

Figure 8 Main components of the GBC ventilation system

\subsubsection{Electrical distribution}

The electrical distribution network is fed from both $34.5 \mathrm{kV}$ and $13.8 \mathrm{kV}$ distribution systems utilizing low resistance grounding and configured both with loop feeds and radial feeds. The system is designed to provide approximately $85 \mathrm{~mW}$ (full production load). There are redundant power feeds for the underground production circuits and non-redundant power feeds for the ore flow circuits. The main electrical backbone is installed and functioning, power distribution to the mine and fixed facilities is proceeding, and development and construction is expanding to the growing production areas.

\subsubsection{Pumping system}

A major source for process water for the concentrator is from the Amole drifts above the GBC production levels that function as drainage for the Grasberg open pit; this is a gravity supply system. The GBC mine is below the open pit and at an elevation below the concentrator. As caving proceeds, water inflows will progressively bypass the upper drifts and will report to the GBC operating levels.

The GBC mine is able to be gravity drained to lower level access drifts ( $A B$ adits) below the GBC operating levels, but the concentrator water requirements dictate that the $G B C$ continue to provide the required water via a pumping system. A 1,600 l/s pumping system will manage the projected drainage requirements from the mine in order to be able to supply the concentrator as required.

A dedicated drainage level is present beneath the haulage level to which all operating levels will drain water via a series of boreholes. Water from the drainage level reports to the main pumping system. The Main Pumping System (MPS) is comprised of three areas: 1) the drainage level channel, capture sumps and overflow system, 2) the lower pump station (LPS), and 3) the upper pump station (UPS). The design pumping capacity of the system is 1,260 l/s with a standby bank of pumps capable of $315 \mathrm{l} / \mathrm{s}$.

The pumping system comprises 10 GIW $10 \times 8,600 \mathrm{hp}$ centrifugal slurry pumps at both the LPS and UPS which will receive the mine water from the drainage level sumps and deliver the water to the concentrating plant. Sixteen-inch diameter pipelines are installed in this dewatering application - one pipeline per pump circuit.

The construction of GBC MPS is divided into two phases. Phase I is being commissioned in 2020 and includes $630 \mathrm{l} / \mathrm{s}$ of operating capacity and $315 \mathrm{l} / \mathrm{s}$ of spare capacity. Phase II consists of an additional of $630 \mathrm{l} / \mathrm{s}$ operating capacity and is intended to be commissioned approximately in 2024. 


\subsection{Rail haulage}

\subsubsection{Rail haulage system description}

A fundamental component of the $\mathrm{GBC}$ mine is the rail ore haulage system. The GBC rail haulage system is the subject of a separate MassMin 2020 paper (Lara et al. 2020). GBC Rail was also the subject of two papers in MassMin 2016 (Hariyadi et al. 2016; Pascoe et al. 2016). Therefore, the section below will only briefly summarize the components and operation of the GBC Rail System.

The primary function of the rail haulage system is to collect ore from the GBC production areas via a series of loading chutes. The rail haulage system is a closed loop system, divided into five main production tracks, with a total of 20 chute galleries, three unloading stations for three underground crushers, and a maintenance and offices area (Figure 9). The layout of the rail system is designed to accommodate the geometries of the production blocks in the caving sequence. The rail lines were laid out so as to not be located directly on the production block boundaries in order to avoid the stress conditions that occur along those boundaries. Once the rail layout had been established and development proceeded, this layout became a constraint for any future caving sequence and production block geometry changes that were considered.

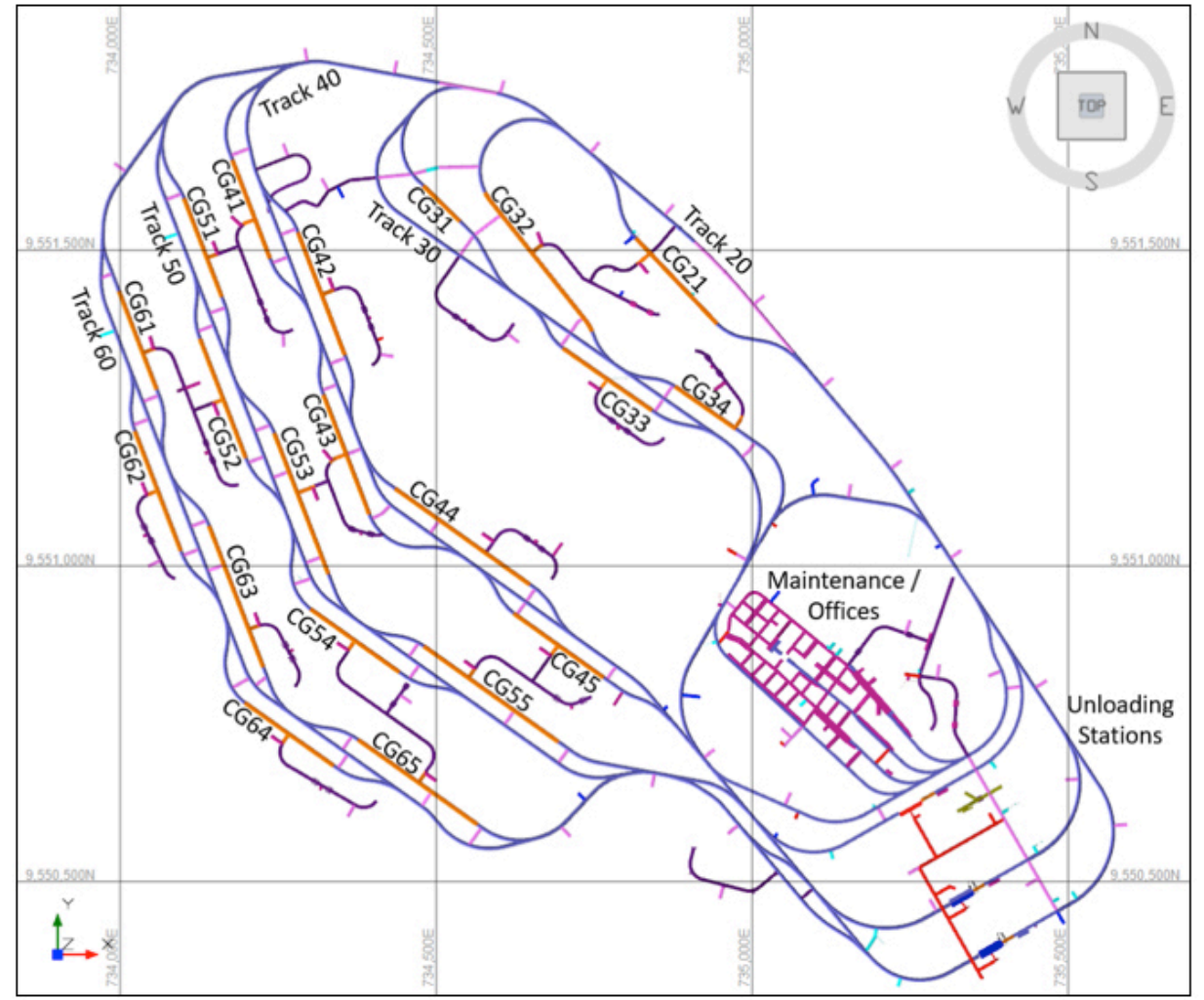

Figure 9 Rail Haulage Layout showing main line, chute galleries, unloading stations and maintenance facilities

The loading chutes are organized into "chute galleries" which are on spurs alongside the main track loops. Figure 10 is a 3D perspective view of a single loading chute, and Figure 11 is a 3D perspective view of a portion of a typical chute gallery. There are between five and nine chutes per chute gallery. The trains load the ore from the chute galleries and deliver that ore to one of three unloading stations which feed the underground crushers. Crushed ore is then delivered to the surface concentrating plant via twin inclined conveyors. The haulage operation is supported by a substantial underground rail shop which is included in the scope of this project. 


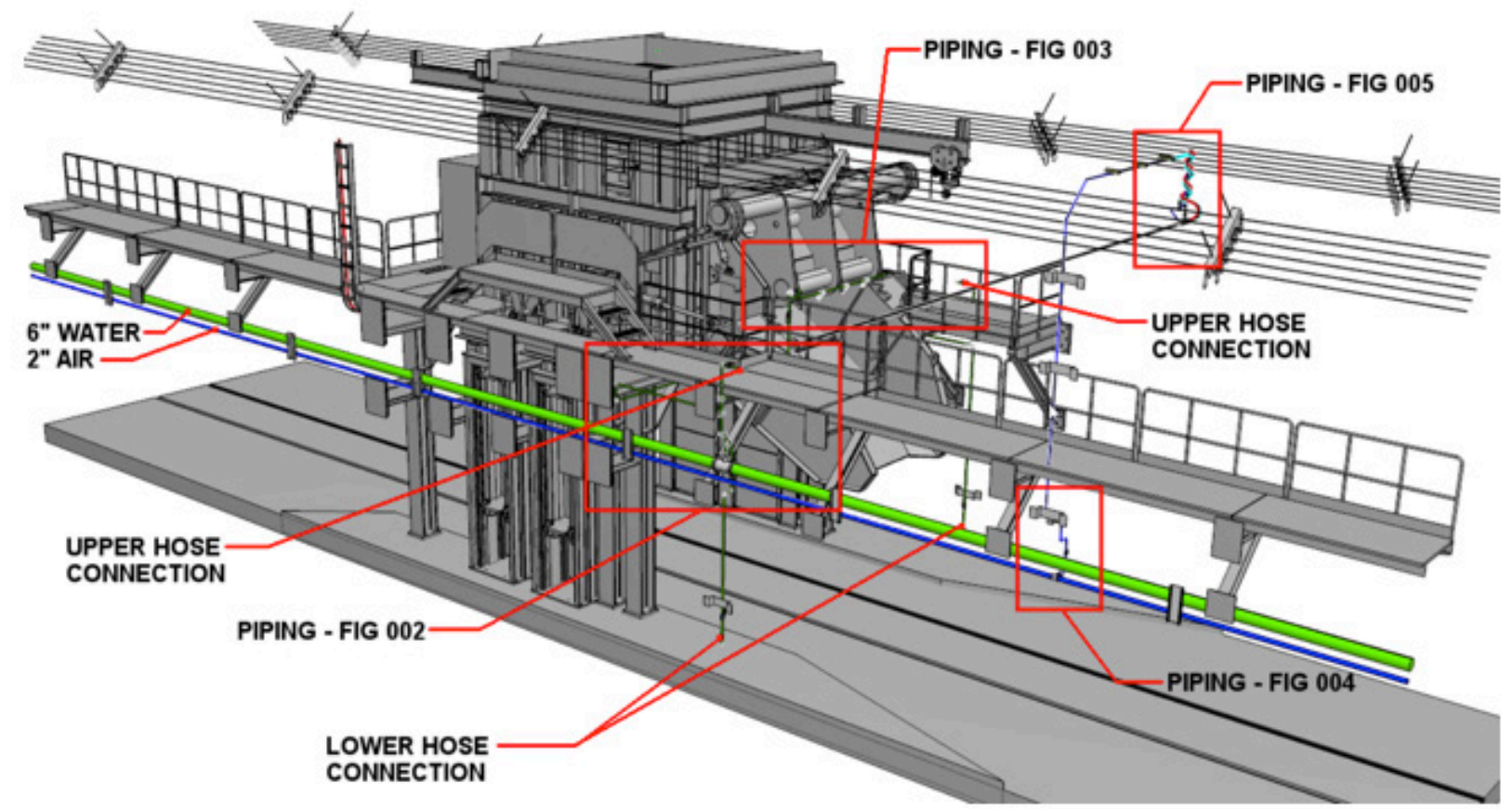

Figure 10 3D image of a typical loading chute station and railway

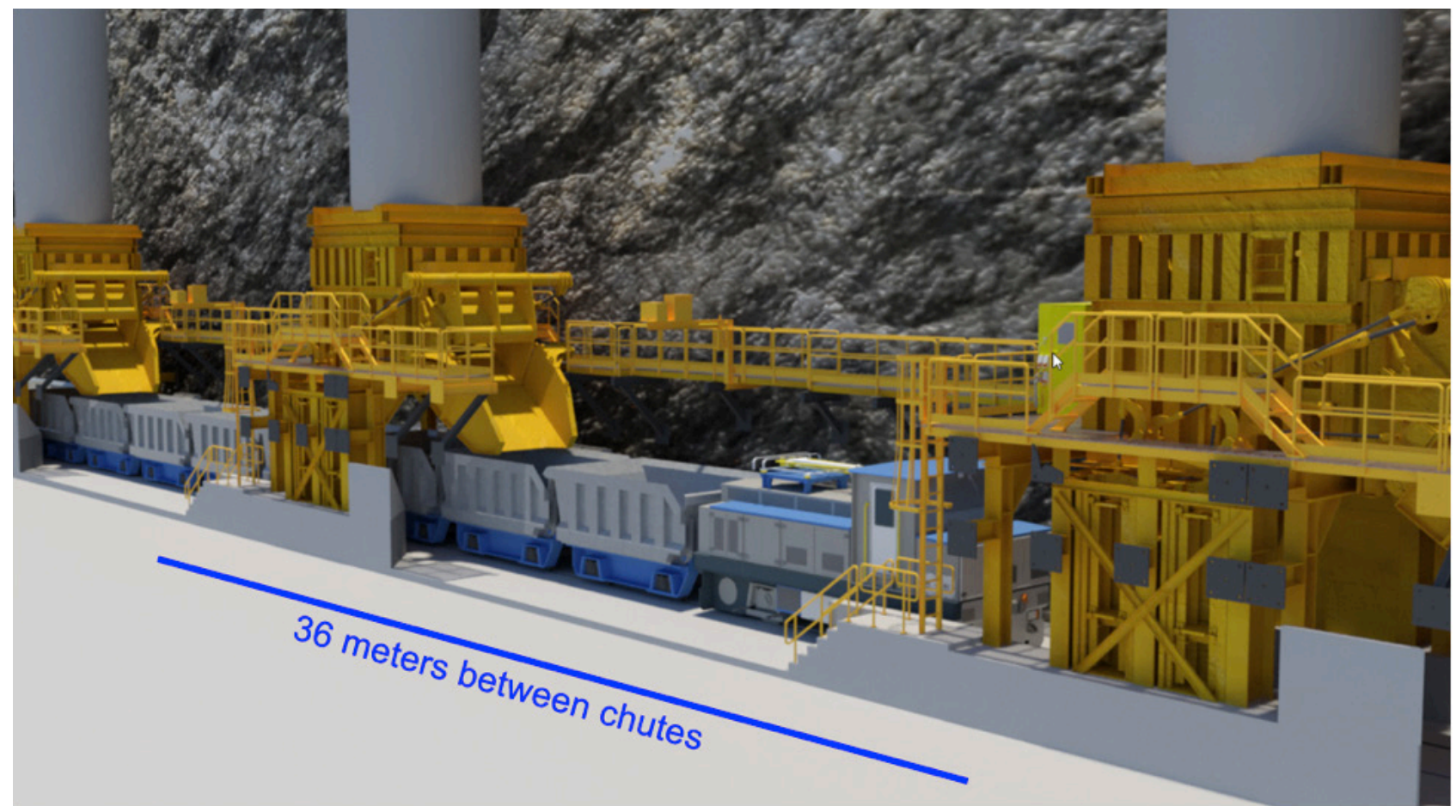

Figure 11 3D image of a typical chute gallery showing the loading chutes for the chute gallery

The scope of the rail project includes all aspects of the ore haulage system from chutes through unloading station to top of ore bins that feed the crushing systems. Ore trains consist of 11 to 12 bottomdump $20 \mathrm{~m}^{3}$ muck cars, driven by a 40- tonne electric locomotive; about 300 tonnes per trainload. Twelve trains and two spares are required to maintain full production at an average 160,000 t/d. The locomotives are powered by an overhead catenary system on the main lines and move through the chute galleries and unloading stations on battery power. All rail installations are 1,435 $\mathrm{mm}$ (standard) gauge with AS60 steel rail. The rail system is designed to operate in full automated mode, including chute loading, muck hauling and dumping. The rail system is controlled from a central dispatch and control room that is located on the surface. 
There will be about $23 \mathrm{~km}$ of track in the fully developed rail haulage system, with about 120 loading chutes. As of June 2020, twenty-six of the loading chutes in the initial five chute galleries are operational, and an additional eight chute stations in two chute galleries are in various stages of construction and commissioning. Eight kilometers of track has been installed to date. The first unloading station is fully operational. Construction of the second unloading station began in November 2019 and is scheduled for commissioning in April 2021.

\subsubsection{Fixed facilities - haulage level}

Facilities on this level support the rail haulage operations, and include the locomotive and ore car shops, rail and rail control system maintenance, and associated lunchrooms, offices, and power distribution. All aspects of the rail system are to be maintained in the rail shop on this level, apart from major rebuilds. The layout of the rail shops is located in the best available ground conditions that could accommodate the mass excavations of the loco and car shops, as well as the satellite maintenance facilities.

The locomotive shop was operational in late 2018 and the ore car shop was operational in mid-2019. Ancillary maintenance facilities and warehousing are in the final stages of construction; those functions are currently being managed in temporary facilities at the rail shop location.

\subsection{Crushing and conveying}

The first $63 \times 89$ inch $(1,000 \mathrm{~kW})$ gyratory crusher complex and associated conveying system was commissioned in July 2018. Excavation of the second crusher station was completed in the fourth quarter of 2019. Construction of the second crusher station, including the rail unloading station, also began in the fourth quarter of 2019 and is scheduled to be commissioned in the second quarter of 2021.

The GBC ore handling system consists of primary crushing plants receiving run-of-mine ore from haulage level trains and delivering $<150 \mathrm{~mm}$ crushed product to the concentrator. The ore is delivered by trains into ore bins and passes through the primary gyratory crushers and onto feeder conveyors to the twin 3 $\mathrm{km}$ long, $1.8 \mathrm{~m}$ wide inclined conveyor systems to the surface secondary cone crusher complex and from there to the concentrating plant. The capacity per crusher is about 60,000 t/d. The maximum average capacity of each of the two conveying systems is about $140,000 \mathrm{t} / \mathrm{d}$.

The GBC ore flow system ultimately will include three crushing stations. Dual conveyor systems will be installed, each including four new conveyors in series. The conveyors are designed for transfer of ore from the crushing stations to the Amole Stockpile at the concentrating plant. Currently a single conveyor line has been constructed and commissioned.

The GBC ore flow system is being constructed in multiple stages. Crushing Station GBC-1 and Conveyor System \#1 that delivers ore to the existing GRS-70 conveyor belt is the first stage. The initial system is operational and construction of Crushing Station GBC-2 has started installation. This second stage will also include Conveyor System \#2 and Crushing Station GBC-3.

\section{Conclusions}

The Grasberg Block Cave mine development began 15 years ago with the initiation of excavation of the $A B$ access tunnels. Emphasis has now shifted from development and construction of the mine to managing those activities while also managing the caving operations and ramping up the mine to full production. The GBC mine will be the largest block caving operation in the world when full production is reached.

The initiation of caving and production has been achieved successfully in the first three production blocks. As the caves expand, the complexity of the operation also will grow for planning and executing the increasing scale of the undercutting, drawbelling and production activities. 
A major challenge is to continue the planning, development and construction of the production infrastructure to accommodate the rapidly advancing cave fronts in multiple production blocks. There will undoubtedly be lessons learned along the way to be recognized and managed in the ongoing effort for the continuous improvement in the operations that will be required to achieve the world-class production targets.

\section{Acknowledgement}

This paper is a brief summary of the mine design, and the progress of the development, construction and early caving results of the Grasberg Block Cave Mine. Contributions to this paper are acknowledged from the underground technical staff at PT Freeport Indonesia as well as from the FCX Strategic Planning team in Phoenix. Development, construction and operations successes at GBC are truly a credit to the massive and undaunted efforts of the GBC operations and engineering teams.

GBC is a world-class operation and could not have been developed without the number of contractor groups that are an integral part of the team at PTFI, including Redpath, RUC, Midroc, Bombardier, Siemens, Nordic Mine Technologies, Stantec, Golder, Beck Engineering, Schalke and Aecom.

The permission of Freeport-McMoRan Inc. to present this paper is gratefully acknowledged by the authors.

\section{References}

Beard, D \& Brannon, CA 2018, 'Grasberg Block Cave mine: cave planning and undercut sequencing', in Caving 2018 - Proceedings of the Fourth International Symposium on Block and Sublevel Caving, eds. Y Potvin and J Jakubec, Australian Centre for Geomechanics, Perth, Australia, pp. 373-384.

Brannon, CA, Firdausi, HH, Pascoe, ND, \& Yuniar, AT 2016, 'PT Freeport Indonesia - Development \& Construction Update of the Grasberg Block Cave Mine', in C Carr \& G Chitombo (eds), Proceedings of MassMin 2016, Australian Institute of Mining and Metallurgy, Sydney, Australia, pp. 625-639.

Campbell, RT, Mardiansyah, F, Banda, H, Tshisens, J, Griffith, C \& Beck, D 2020, 'Early Experiences from the Grasberg Block Cave: A Rock Mechanics Perspective', in Proceedings 8th International Conference on Mass Mining, MassMin 2020, Santiago, Chile.

Campbell, R, Banda, H, Fajar, J \& Brannon, C 2018, 'Optimising for success at the Grasberg Block Cave', in Proceedings of the Fourth International Symposium on Block and Sublevel Caving, eds. Y Potvin \& J Jakubec, Australian Centre for Geomechanics, Perth, Australia, pp. 3-16.

Hariyadi, A, Castro, M, \& Fisher, JB 2016, 'PT Freeport Indonesia - Grasberg Block Cave Rail Haulage Project: Automated Ore Train System', in C Carr \& G Chitombo (eds), Proceedings of MassMin 2016, Australian Institute of Mining and Metallurgy, Sydney, Australia, pp. 563-570.

Lara Moran, F, Brannon C, Hariyadi, A, Castro M, \& Gillman J 2020, 'Grasberg Block Cave Mine Rail Project Update - PT Freeport Indonesia', Proceedings of MassMin 2020, Santiago, Chile.

Pascoe, N, Mead, B, Vega, H, \& Azizi, T 2016, 'PT Freeport Indonesia - Grasberg Block Cave Rail Haulage Project: Design and Construction Update', in C Carr \& G Chitombo (eds), Proceedings of MassMin 2016, Australian Institute of Mining and Metallurgy, Sydney, Australia, pp. 585-598. 